\title{
Cross-border trade union networks in transnational corporations \\ A comparison between sectors
}

\author{
Ricardo Framil Filho* \\ https://orcid.org/0000-0001-8212-6974 \\ Katiuscia Moreno Galhera** \\ https://orcid.org/0000-0001-5790-0913 \\ Leonardo Mello e Silva* \\ https://orcid.org/0000-0003-0753-7110
}

Introduction

The rise of a "new labor internationalism" in the era of globalization has been a matter of contention in the field of labor studies. Original conceptualizations of the notion explored the potential affinity between unions and broader social movements around the turn of the century (see Waterman \& Wills, 2001). Some interpreted emerging transnational labor networks as part of a "counter-hegemonic globalization" (see Webster et al., 2008), while critics called into question the very existence of the phenomenon (see Burawoy, 2010). Lately, a growing body of research on the subject has allowed for more nuanced analyses, suggesting that, in practice, diverse "labor internationalisms" should not be viewed as an "all-or-nothing endeavor" (O’Brien, 2019, p. 1).

This article focuses on a specific kind of cross-border labor activity - union networks that are grounded in local instances of global production and target specific transnational corporations (TNC). Such networks have been at the center of recent debates on new labor internationalism, and have sparked interest, above all, because of their potential to connect transnational initiatives to grassroots, "bread and butter" labor struggles in workplaces, offering an alternative to the "diplomatic"

* Universidade de São Paulo, São Paulo, Brasil.

** Universidade Federal da Grande Dourados, Mato Grosso do Sul, Brasil. 
practices of previous forms of international union organization (see Wills, 1994; Fairbrother \& Hammer, 2005; Cumbers et al., 2008; Lambert \& Gillan, 2009). At the global level, union networks in TNCs have been associated with the policies of Global Union Federations (GUFs), international bodies that bring together unions in specific industries or professional categories. However, it has been generally acknowledged that global unions do not have the material or legal means to organize workers directly, relying instead on the support of local and national unions to carry out actions in different territories (see Garver et al., 2007; Croucher \& Cotton, 2009). In this sense, GUFs are perhaps best thought of as "intermediaries or facilitators in multi-scalar initiatives" (Ford \& Gillan, 2015, p. 14), articulating previously established union organizations.

Nevertheless, engaging TNCs in this manner has been used to rescale the scope of trade union action and to push for the creation of new union powers. The most notable examples are the mandates claimed by GUFs that are presented as global union counterparts to TNCs. This ambition is supported by numerous unions organizations and its legitimacy has been implicitly recognized by powerful TNCs that have signed Global Framework Agreements (GFAs) with global unions in the last decades (see Gallin, 2008; Hadwiger, 2018), but this new field of union organization is not immediately regulated by public authorities and companies cautiously frame it as a form of "weak social dialogue within the parameters of corporate social responsibility" (see Stevis, 2011, p. 117). Indeed, we are witnessing the making of a field that is still actively contested and reflects the "transitory nature of ongoing processes within an emerging arena of the global governance of labor" (Helfen \& Fichter, 2013, p. 556).

In this article, we suggest that this kind of informal, gradual, and often hesitant rescaling and rearranging of trade union prerogatives prompted by the targeting of TNCs outside of traditional industrial relations frameworks can also occur within national boundaries. We are particularly interested in studying how trade union networks tentatively create new union jurisdictions (in terms of subjects, powers, or geographical scope associated with different union mandates and organizations), and how this process is shaped and constrained by the interactions among unions embedded in previously established institutional frameworks, and between them and corporate powers. To this end, our study analyses the development and operation of trade union networks in four sectors in Brazil: metal and chemical manufacturing, garment production, retail business, and commercial banking. 
Definitions and scope

\section{Trade Union Networks in Transnational Corporations}

For the purposes of this study, we define cross-border trade union networks in TNCS (from here on, TUNs or networks) as voluntary alliances that, targeting specific corporations and grounded in their operations in different localities, articulate independent union organizations across borders to create spaces of labor organization and industrial relations that would not have been possible for participant organizations on their own, reaching beyond traditionally recognized trade union prerogatives in different settings. In essence, TUNs emerge when union structures are deemed insufficient to deal with the growing power and reach of complex production networks, prompting a relatively informal, tentative response to overcome these limitations. In the studied cases, three defining features stand out:

1. TUNs are grounded in processes of trans-local production of goods and services, connecting workers and union representatives in tangible workplaces across multiple localities;

2. The boundaries of individual TUNs are defined by a correspondence to specific transnational corporations, or "target-companies";

3. Tuns carry an implicit challenge to traditional frames of trade union action but do not break away from (and, in fact, are directly connected to) established union organizations.

\section{Cross-border TUNs in Brazil}

Although our main frame of reference is the operation of TUNs in Brazil, the networks analyzed in this article were invariably the result of interactions of union leaders operating in different places and scalar levels, which compelled us to cover a wide range of organizations. At the global level, we have analyzed two major global unions - Industriall Global Union, the main international union body in manufacturing industries, and Union Network International (UNI Global Union), the largest GUF in private services. We have also taken the role of major foreign supporters of TUNs into account, such as the United States-based Solidarity Center and the German union confederation Deutscher Gewerkschaftsbund (DGB). Moreover, the observation of networks in action has allowed us to get in contact with union leaders from different countries. In Brazil, we have considered the policies of union centrals and national industrial confederations, and local unions affiliated to them. 
We have conducted interviews with current or former leaders of every organization mentioned by name in this article, besides many others; observed several union events and activities; and analyzed documents and grey literature, including internal reports and minutes on the operation of TUNs, dated from the early 2000s to 2020.

From a multiscale research framework, it's worth mentioning a brief outline of institutional features of the Brazilian trade union organization. In Brazil, unions have a monopoly over both collective bargaining prerogatives and union organization rights in state-regulated professional and territorial jurisdictions. In essence, only one union can represent a specified category of workers (e.g., metal workers, banking workers etc.) in a delimited territorial basis (e.g., the city of Rio de Janeiro, São Paulo, and so). Brazilian unions have often defied these determinations. For instance, "union centrals" operated informally for decades until they were officially sanctioned in 2008. Similar to international union bodies, union centrals and national industrial confederations in Brazil have limited powers and affiliate local unions rather than workers. Accordingly, networks targeting companies present in multiple localities in the country have been vehicles for national organization at the same time as they promoted international connections. The use of the expression "cross-border" instead of "transnational" is therefore deliberate - it indicates that TUNs in Brazil may be used to bridge internal borders as well as external ones.

\section{TUNs in Four Sectors}

\section{Metal and chemical manufacturing}

In Brazil, traditional manufacturing unions that spearheaded impressive workers' strikes since the late 70 s started to face the impacts of globalization in the following decades. Transnational corporations established in old industrial clusters (notably, the "АВC" region in the state of São Paulo) went through restructuring processes under the auspices of global corporate determinations, spreading to "green fields" out of the reach of established unions. Suddenly, the usual methods of local unionism, based on mobilizing workers in specific factories and localities, were not as reliable as they had traditionally been. The response from unions affiliated to the Unified Workers' Central (CUT), which would become the most active supporters of TUNs, was threefold. At the national level, unions in different parts of the country started to cooperate, attempting to give union action in specific industries a national character, which paved the way to the creation of national industrial confederations and included the demand for a national labor contract (see Véras, 2006; Oliveira, 2006). At the international level, local unions sought out foreign allies, in particular 
unions at major companies' headquarters, hoping to find a path to influence global executives (see Anner, 2006). Cutting across scales, finally, unions moved away from "combative" stance to incorporate a "social-democratic" agenda (see Antunes, 2000).

The first cross-border union networks in TNCs in Brazil appeared in the chemical and metal industries and combined these trends with global union efforts emerging at the company level, establishing a model that would later be adopted (and transformed) in different sectors. An illustrative example is the union network in the German chemical manufacturer Basf. Contacts between the Chemical Workers' Union of the $\mathrm{ABC}$ and German unionists date back as far as the 1980s and, around the same time, union representatives in the region sought out connections with workers employed by the company in other locations in the country, including those in the states of Bahia, Rio Grande do Sul and Amazonas. The National Federation of Chemical Workers (CNQ-CUT) was founded in 1992. Under regular circumstances, national industrial federations have a limited role in collective bargaining in Brazil but can be important to promote alliances between union representatives across localities, and are often responsible for promoting international relations on a sectoral basis.

Between 1990 and 1994, meetings of chemical workers in German companies (including Basf) were held in Brazil and Germany, and in 1995 the $\mathrm{CNQ}$ formally joined the sector's Global Union Federation. In 1999, Icem (ex-CNQ and currently Industriall Global Union) organized the first International Meeting of Basf Workers, symbolically held in the ABC region in São Paulo. A global union network was formally established alongside a national "inter-union" structure, the Intrab. The exchanges with foreign unions allowed local unions to strengthen relationships with important allies and, since the earlier contacts in previous decades, German industrial relations and social partnership practices offered an appealing paradigm for unions accustomed to being fiercely opposed by local corporate managers.

The history of the network in Basf has been turbulent and involved moments of open confrontation, including notable strikes that disrupted relations with the company. Nevertheless, having established considerable shopfloor influence, unions were able to achieve important changes. Notably, yearly rounds of "social dialogue" were established between the company and unions organized within the network, allowing leaders from different factories in the country to engage in supra-local spaces that are best defined as an attempt to mimic the practices of European Works Councils at the national level in Brazil and, occasionally, the international level' ${ }^{1}$.

1. Through networks, Brazilian unionists in certain companies have been invited to participate as observers in Works Councils in Europe, and some are proper members of world committees. 
In these events, local leaders present grievances that could not be resolved locally, are informed about corporate plans and results, and sometimes engage in collective bargaining in regards to benefits and bonuses, although wages are out of the scope of such meetings.

This model has been replicated in different TNCs in the metal and chemical industries in Brazil, with varying degrees of institutionalization. It is more likely to be adopted in companies that are accustomed to working within social partnership arrangements, usually European corporations, but it has been successfully pursued in TNCs from different backgrounds. There are two main goals. First, the "recognition" from the company, which often means corporate financing of network activities, but at a minimum involves the acknowledgement of the network as a legitimate counterpart. Second, the establishment of "social dialogue" across different scales, from the introduction of workplace union representatives to the aforementioned dialogue rounds.

As much as global unions and national confederations may be vital as "catalysts" of trans-local connections, any mandate granted to the network is an extension of the legitimacy and legal rights of local unions that voluntarily participate in the initiative. Accordingly, issues discussed within networks are primarily those that concern local unions in their usual undertakings - working conditions and labor conflicts, wages and benefits, the right to organize, etc. The most glaring limitation of this model is that it does not challenge or expand the membership of participating unions. These are, effectively, networks of local unions, union officials and unionappointed workplace representatives, a structure that tends to exclude contract, outsourced, and office workers, in addition to those employed by suppliers of major TNCs, because these groups are usually underrepresented in the local unions that drive these alliances. In sum, TUNs in the metal and chemical industries represent the effort of local unions deeply rooted in specific plants to reach beyond the local in response to the changing industrial environment within major manufacturing TNCS.

\section{Garment industry}

Networks organized in traditional manufacturing strongholds regarding to union organization have a few advantages over those seeking to establish a foothold in sectors such as the garment industry, in which production is much more spread out. First, it is not unreasonably difficult to charter the production of capital-intensive manufacturers operating a tangible number of factories around the world, but it is a different situation in labor-intensive industries in which production involves the coordination of thousands of workplaces that are not directly owned by the target- 
company. As a matter of comparison, Basf claims to operate 241 production sites in 90 countries, and their addresses are readily listed on the company's website. When CUT's research arm that supported the development of TUNs studied the operations of the company in Brazil, the network's "roadmap" in the country consisted of 9 factories. On the other hand, Inditex, a Spanish corporation in the clothing business and owner of global brands such as Zara, declares to "work with" 8,155 factories "declared by" 1,985 suppliers worldwide (see Inditex, 2020). Indeed, the availability of this kind of information was the result of pressure from workers, unions, and other social movements that fought the invisibility of labor in the garment business. The challenge, of course, is not only to map workplaces, but to use this information to connect workers and their leaders on the ground. Here, there is a second disadvantage. While metal and chemical unions often have an established presence in factories, garment unions must navigate everchanging production networks characterized by informal employment relations, anti-union practices, and precarious labor.

Given the absence of union presence across workplaces, the Global Union Federation (Industriall Global Union) plays a larger role in garment networks, operating as the main promoter and coordinator. In the case of Inditex, the idea is that "as a global organization, Industriall has the capacity to reach and defend workers spread out across the group's enormous supply chain" (Industriall, 2014, p. 20). In practice, things are more difficult. Global unions usually lack the resources to sustain a continuous engagement with factories spread out over vast territories. In Brazil, accordingly, global efforts in Inditex were supported by foreign unions, but also by a variety of national union organizations, including the national industrial confederations in the garment sector affiliated to CUT and Força Sindical. There is also a distinct presence of non-union organizations, such as NGOs and advocacy networks created as part of anti-sweatshop movements. Thus, the global mandate claimed by GUFs does not immediately translate into the necessary organizational capacity to reach out to workers and workplaces and does not imply the recognition of the legal right to exercise trade union prerogatives within specific territories, so the network's reach is limited and shaped by pre-existing forms of organization.

On the other hand, in workplaces where unions are absent, instruments such as Global Framework Agreements secure global unions a certain degree of legitimacy to reach out to workers directly. A GFA signed with Inditex in 2007 has allowed IndustriaLL to inspect several factories associated with the company in different countries, a process that acknowledged the right of global union officials to speak to workers. Furthermore, the agreement was amended in 2014 (a further revision was made in 2019) to include protocols regarding the right to organize unions across the company's production networks, and Industriall took advantage of its inspection duties to 
forge connections with local union leaders (see ccoo Industria, 2017). Finally, the union network has been used to conduct solidarity campaigns and training efforts in the hopes of boosting union militancy across the company's production networks.

Despite these efforts, important groups of workers employed in the company's operations are underrepresented in the network - notably, immigrant women submitted to informal or non-waged forms of exploitation. In Brazil, contacts have been sparse and focused on training efforts whose reach is mostly limited to workers already in contact with trade union organizations. Often, furthermore, the introduction of private certification instruments, instead of transforming sweatshop labor to adhere to the standards of formal employment, simply excluded the worst offenders from the networks of covered TNCs, thus maintaining their workers out of the scope of the protections associated with such regulations. For the most part, the network itself is used to arrange summit meetings, and to monitor compliance to Corporate Social Responsibility norms and the enforcement of the GFA. So far, the Inditex network embodies a top-down, paternalistic approach, although the global union has been pursuing conditions that could, in time, allow proper local union organization to flourish. In sum, it represents a global union using an uncertain global mandate to reach for the local.

\section{Retail commerce ${ }^{2}$}

In the retail business, the typical workplace operated by a transnational corporation is not the factory but a store that exists alongside thousands of similar establishments managed by the big chains in the sector. Much like other businesses in the service industries, the atomization of union representation in Brazil is pronounced, and the prevalence of high turnout and precarious labor are urgent concerns. However, there are also features that favor union organization in the sector. First, major chains hire most of their workers directly or at least go through formal employment arrangements, allowing unions to operate within established frameworks of industrial relations. Second, workplaces are open to the public, making it easier for unions to engage workers, despite corporate anti-union practices. Third, companies cannot simply relocate physical stores to localities out of the reach of established unions. This last point is particularly relevant in major cities, where retail unions have a large potential member base and can amass considerable influence.

2. The findings on retail commerce benefited largely from a previous research led jointly by Scott Martin, João Carlos Candia Veiga and Katiusca Galhera (2021). The conclusions drawn from that research, however, are independent from those reached in this article. 
Unions affiliated to CUT's National Confederation of Workers in Commerce and Services (Contracs) were among the first to be involved in the central's efforts to expand TUNs beyond traditional manufacturing sectors. One of the first targeted companies was Dutch retailer Royal Ahold, then established in the North-eastern region of the country under the brand Bom Preço. Shared demands were presented to the global president of the company in 2002 and, in that same year, 12 union organizations (local unions and sub-national federations) attended a meeting in Salvador (BA) to discuss the creation of a network. In the event, Ahold's Code of Conduct was a rallying flag. Unions took notice of the "contradictions between what is written and [Ahold's] practices", and it was said that "there are two codes Ahold's and Bom Preço's! The company insists on adopting only the Brazilian one, saying that the Netherlands is the Netherlands, Brazil is Brazil"3. This is illustrative of the fact that, despite the common association between global union strategies and European industrial relations frameworks, the pragmatic use of European standards to pressure TNCs is not exclusive to traditional manufacturing unions in which social partnership practices are presumed to be seriously considered.

In 2004, Walmart bought Bom Preço from Ahold, and a network was soon set up in the company. Brazilian leaders took part in several meetings organized by UNI Global Union to organize unionists dealing with Walmart around the world, but, at the national level, the topics discussed within the network coincided with those of local unions: the demand that dismissals be "validated" by local unions ${ }^{4}$; problems with broken equipment and refrigeration in certain stores; complaints about corporate anti-union practices, such as not allowing union leaders to distribute leaflets in stores, etc. ${ }^{5}$ Further on, "social dialogue" in Walmart in Brazil would take the form of yearly bargaining rounds where, among other things, a national profit-sharing bonus paid by the company to workers to all workers is negotiated.

Other TUNs promoted in the sector follow the same pattern. At the surface, networks in retail are strikingly like the ones organized in traditional manufacturing - they connect local unions and pragmatically use social responsibility discourses to expand the scope of union representation and organization in TNCs. In fact, the criteria used by Contracs to measure the success of a network are very similar to the ones used in the metal and chemical industries, privileging the company's "recognition" the establishment of "social dialogue", in accordance with the early CUT guidelines for TUNs. However, there are subtle, yet important differences. Where local unions are not as

\footnotetext{
3. Internal report, Contracs.

4. A provision of the national labor legislation that, until recently, gave local union the right to oversee dismissal procedures.

5. Internal report, Contracs.
} 
well established, union organizations with no enforceable mandate of their own, such as global unions and national industrial confederations in Brazil, may use networks to reach out to workers directly, and even to engage in collective bargaining processes. For instance, the UNI Global Union has been directly involved with campaigns and protest actions and Brazil. Moreover, given the large number of local unions dealing with the company, leaders of the major national confederations are directly involved in the bargaining processes associated with social dialogue rounds.

Because local unions are protective of their prerogatives, however, this tentative national mandate is asserted gradually, often informally, and not without a degree of ambiguity. In 2018, Contracs released a poster calling for workers in the company to gather in assembly to discuss the subject, much like a proper union would, but the actual, formal notice was addressed to affiliated local unions that would organize their own bases. In the same vein, one of the first bulletins of the Walmart network in Brazil made sure to acknowledged that "each union has its own reality and strategy, and the union committee does not want to change the strategies of each organization". Indeed, the alternating use of "Contracs committees" and "union networks" is further evidence of this uncertainty. In essence, TUNs in retail commerce in Brazil represent a hesitant attempt to gradually centralize organization and bargaining, reaching for the local in pursuit of a scale shift.

\section{Commercial banking}

The distribution of workplaces in commercial banking could be compared to that of retail chains and other service industries - workers are in thousands of local branches operated by one of the major commercial banks, usually highly centralized transnational corporations. Banking workers are better employed than those in more precarious service industries, such as retail, but they have long been under pressure from management and technological transformations. The digitalization of services and the use of call center workers to perform actions traditionally associated with banking workers, for instance, have been major sources of union activity. Continuing a tradition of trade union militancy through frequent strikes in the last three decades, they have been able, so far, to preserve important benefits, such as a 30-hour workweek ( 44 is the standard in the country) and an above-average wage floor.

Regarding our research questions, the most important distinction of the sector is that, unlike virtually every other working-class professional category in the country, banking workers have secured nationwide labor contracts since 1992, the result of determined struggles that included a national strike in 1985 . Indeed, although the basic contract is the same for every bank, there are national "commissions" that or- 
ganize union leaders within a target-company across different levels in the country. Unlike Tuns, however, these bodies have achieved a high level of institutionalization and take part in proper, uncontested collective bargaining processes, effectively "nationalizing" trade union action in commercial banking in Brazil.

In this sense, banking unions start from the point that most networks in other sectors aspire to achieve - national collective bargaining with major TNCs. Therefore, TUNs in the sector in Brazil have been primarily used to forge international connections. Perhaps more than in any other industry, the international development of TUNs in commercial banks was in no small part the result of the efforts of leaders linked to CUT. Leaders working within CUT's National Confederation of Workers in the Finance Sector (Contraf) engaged in international initiatives early on (see Castro, 2016), and are active members of Union Network International (UNI Global Union), the largest GUF in services industries. In practice, the industrial branch within the UNI's regional arm (UNI Americas Finances), in which Brazilian leaders play a decisive role, became the main international supporter of company-based networks in commercial banks. Broader connections are not absent, but TUNs in the sector are established with a markedly regional focus, even in the case European banks ${ }^{6}$. In a way, TUNs in the sector followed in the footsteps of Contraf's international policies, which privileged Latin American alliances. This focus was influenced by national ambitions of regional leadership, integration, and solidarity in the wake of the Workers' Party ascendance to power in 2003, a trend that characterized cuT's international politics as a whole in this period but also represented a reaction to the growing reach of major Brazilian banks in the neighboring countries. Moreover, TUNs in the sector are less focused on company-specific issues, often privileging broader industrial concerns and political issues?

UNI Finances Americas' TUNs gather once a year, invariably in a Latin American country, for a "joint meeting" that unites all networks. The $14^{\text {th }}$ meeting, held in Peru in 2018, for instance, occurred alongside the $5^{\text {th }}$ meeting of the Latin American Alliance in Defence of Public Banks, and international forums on pension funds and digitalization in the financial system. In the same vein, instead of single-company bulletins, there was a joint "Global Banking Workers Network" pamphlet, published by UNI Americas, Contraf, and the Coordination of Union Centrals in the

6. UNI Americas has signed two GFas with two commercial banks headquartered in Brazil - Banco do Brasil and Itaú Unibanco. An oddity of these agreement is that, although they are usually listed as GFAs, in both cases the territorial coverage is explicitly defined as 'the American continent'. In addition to these banks, there are networks in Santander, HSBC, BBVA and ScotiaBank.

7. The existence of public banks in Brazil is relevant in this regard. Workers have a seat at the board of Banco do Brasil, for instance, which gives them direct influence on public policies. 
Southern Cone. TUNs do opera, and they are used to tackle issues related to each target-company but they are comparatively more likely to combine top-level pressure over company-specific demands (such as particular corporate policies, or cases of workplace harassment and gender discrimination), industrial campaigns that relate to outsourcing and the impacts of digitalization, and efforts to legitimize global unions. In the Spanish bank Santander, for instance, "continental journeys of struggle" demanded, at the same time, a Global Union Framework, profit-sharing bonuses, and the end of outsourcing. Although this implies a more usual "international relations" approach, it does not represent a step back towards an internationalism that is distanced from struggles at the frontlines. In sum, the Brazilian experience with TUNs in the banking sector reflects a strong trade union movement with a national basis reaching for primarily regional alliances that, nevertheless, take the lead in efforts that are global in outlook, such as the signing of GFAs.

\section{Comparative analysis}

\section{A frame of comparison}

Our research confirms the generally accepted conclusion that sectoral features are important determinants of cross-border union action (see Anner et al., 2006), yet here we have focused, primarily, on the relationship between emerging union networks, previously established institutional structures, and the engagement with TNCs as an alternative means of legitimization of union prerogatives. In each of the studied cases, a coalition of labor organizations takes advantage of a transnational corporation's productive structures (as a "roadmap") and private authority (as a "counterpart") to pursue a scale shift that tentatively rearranges the scope and roles of trade union organizations within a given context. The outcome is the creation of cross-union alliances and industrial relations practices (usually under the umbrella terms "networks" and "social dialogue", although often with different meanings) that imply the de facto acknowledgement of new union prerogatives that are accommodated to (i.e., do not disrupt) traditional structures.

Table 1 summarizes our findings, taking as the reference in each sector the position of what we define as "key participants". By that, we mean the main drivers of networks in different sectors, the kind of organization that better represents the "scalar shift" described in each case ${ }^{8}$ : local unions seeking to establish primarily na-

8. This is a simplification and implies an analytical perspective, of course. In practice, there are multiple shifts at play. A strong network may, for instance, lend credence to the global mandate claimed by a 
TABLE 1

Company-based TUNs in Different Industries in Brazil

\begin{tabular}{lllll}
\hline & METAL/CHEMiCAL & GARMENT & RETAIL & BANKING \\
\hline $\begin{array}{l}\text { KEY } \\
\text { PARTICIPANTS }\end{array}$ & Local Unions & Global Union Federation & National Confederation & National Delegations \\
\hline SCALAR SHIFT & Local $\rightarrow$ National & Global $\rightarrow$ Local & National $\rightarrow$ Local & National $\rightarrow$ Regional \\
\hline $\begin{array}{l}\text { UNION } \\
\text { RELATIONS }\end{array}$ & Translocal connections & Top-down support & $\begin{array}{l}\text { Hesitant national } \\
\text { centralization }\end{array}$ & $\begin{array}{l}\text { Latin American } \\
\text { solidarity }\end{array}$ \\
\hline CONSTITUENCY & $\begin{array}{l}\text { Unionized, directly } \\
\text { employed }\end{array}$ & $\begin{array}{l}\text { Non-unionized, } \\
\text { supply chains }\end{array}$ & $\begin{array}{l}\text { Partially unionized, } \\
\text { directly employed }\end{array}$ & $\begin{array}{l}\text { Mostly unionized, } \\
\text { directly employed }\end{array}$ \\
\hline $\begin{array}{l}\text { SUBJECT } \\
\text { MATTERS }\end{array}$ & $\begin{array}{l}\text { Specific workplace } \\
\text { demands }\end{array}$ & $\begin{array}{l}\text { Human rights and labor } \\
\text { violations }\end{array}$ & $\begin{array}{l}\text { Diffuse workplace } \\
\text { demands }\end{array}$ & $\begin{array}{l}\text { Company-related, } \\
\text { broader concerns }\end{array}$ \\
\hline PRIMARY SCOPE & National & Global & National & Regional \\
\hline $\begin{array}{l}\text { INDUSTRIAL } \\
\text { RELATIONS }\end{array}$ & $\begin{array}{l}\text { Conflictive } \\
\text { Partnership }\end{array}$ & $\begin{array}{l}\text { Corporate Social } \\
\text { Responsibility }\end{array}$ & Collective Bargaining & Top-level pressure \\
\hline
\end{tabular}

Source: Original research.

tional arrangements in traditional manufacturing industries; a global union reaching for the local in the garment case; a national confederation attempting to centralize union organization and collective bargaining privileges in the retail business; and the efforts of the banking workers' union movement to leverage a strong national basis to achieve regional influence. Moreover, each column presumes a labor "constituency" (workers that are conceived of as the social base of the network); an affinity with certain "subject matters"; tentatively creates a new scalar "jurisdiction"; and particular approaches to "social dialogue" and industrial relations, that is, different forms of engaging the target-company.

When read together, these cases indicate that there are no natural jurisdictions, ready-made constituencies, or exclusive issues in the scope of union networks in TNCs. They suggest a range of possibilities, not a single model. Furthermore, our results suggest that TUNs can reorganize union roles within national settings. Nevertheless, our findings also shed light on the fact that TUNs often preserve traditional definitions regarding to which workers, workplaces, and employment relations are assumed to be in the purview of union organizations and associated networks. Union leaders are aware of these limitations and address them within TUNs, but they do not pick and choose the features in the table freely, rather they are constrained by

guf at the same time as it carves out new prerogatives for a national industrial organization. The table highlights the relationship between networks and the Brazilian trade union structure, and prevalent features as illustrated by the cases presented in the previous section. 
industrial settings and institutional frameworks. Therefore, our aim is not to find the one best model, but to reflect on what is at stake.

The persistence of traditional labor boundaries is indicative of broader trends that relate to debates on the continued relevance of collective bargaining and trade unions, or the risks and benefits of regulatory approaches based on private governance arrangements. In more specific terms, leaders attempting to broaden the scope or deepen the roots of TUNs in Brazil face three main obstacles. The first two have to do with inherent limitations of the institutional trade union structures in the country. First, it is illegal for union organizations (or informal networks, for that matter) to engage in collective bargaining and proper trade union organization on behalf of workers without the consent of the local union officially assigned to them. Second, under adverse conditions, unions may be compelled to prioritize their core member base, even if they profess broader solidarity principles. In other words, being trade union networks, such alliances are constrained by the structures from which they emerge. Finally, a third challenge is related to the ways through which TUNs use TNCs to legitimize claims over new prerogatives and spheres of action. The private authority of powerful corporations is not neutral, it shapes "social dialogue" practices. We now turn to these questions.

\section{Old boundaries, emerging networks}

The search for union "counterbalances" to global corporations reflects the perception that the growing reach and power of TNCs have created the need for matching union responses. Indeed, promoters of $\mathrm{TUN}$ S often refer to the mantra of a correspondence between the networked character of current global corporations and the desirable union mode of organization, that is, trade union networks. However, the connections established via TUNs do not exactly coincide with the makeup of production networks. The paradigmatic case is that of metal and chemical industries, where TUNs' constituencies are closely related to the core member-base of participating unions (mostly, male workers directed employed by target-companies in production), despite the acknowledgement of the importance of contract, office and suppliers' workers. In retail, likewise, TUNs implicitly accepted traditional union boundaries, privileging the experience of workers formally and directly employed by TNCs, even though in this case the relative weakness of local unions allowed for a tentative national centralization.

In the garment industry, on the other hand, the uncertain global mandate proclaimed by a GFA was used to follow the trail of proper GPN connections. However, the lack of an established union presence in workplaces significantly impaired the 
effects of the network in Brazil. Finally, TUNs in commercial banking combined company-specific demands with broader industrial concerns, targeting TNCs to, among other things, demand the expansion of the scope of labor rights currently restricted by a narrow definition of "banking workers" that exclude outsourced call center employees. Even in this case, however, TUNs were not the main driver behind this shift. They reflected the national achievements of a strong and exceptional movement that had already addressed important limitations of trade union organization in Brazil.

Therefore, our conclusion is that TUNs, being directly connected to established union structures, assimilate some of their boundaries and exclusions. It is important to note, however, that TUNs are not detached from broader efforts. In traditional manufacturing sectors, in which the influence of local priorities is hardest to escape, demonstrations of shopfloor solidarity with contract, cleaning and catering, maintenance, and office workers are not uncommon, and local representatives leverage the influence achieved through TUNs to support these groups. In a recent case, moreover, a network in an automaker took it upon itself to organize workers in a supplier plant outside of the jurisdiction of participating unions. This is an exception, but it shows that institutional constraints do not necessarily lead to resignation.

An interesting development has been the creation of IndustriaLL Brasil in late 2020. Openly inspired by the model adopted by the homonymous global union, it was not conceived as a national chapter, but as a new, independent organization that brings together CUT and FS affiliates in metal, chemical, textile and garment, construction, food and catering, and energy industries. Similarly, within CUT, a "services macro-sector" working group has been discussing joint strategies with unions in finances (including commercial banking), communications, private security, retail commerce, and data processing. In sum, union boundaries are actively being challenged, although not strictly via networks. Presumably, TUNs can be one element in a larger process of reorganization, and the fact that inspiration is being taken from global unions in the pursuit of alternatives is an evidence of their role in this regard.

\section{Corporate Governance and Social Dialogue}

We have shown that TUNs use CSR discourses pragmatically, so the formal commitment to "social dialogue" should not be viewed as an acceptance of the idea of leaving capital-labor conflicts behind. McCallum (2013, p. 13) associated union efforts in this regard with "governance struggles", defined as "a panoply of strategies to subordinate the rules-based logic of private companies to democratic oversight by workers and their unions". Nevertheless, once "social dialogue” is institutionalized, 
establishing a set of rules and compromises that guide the relationship between unions and managers within a sphere of private governance, TNCs can shape it to a significant degree. In fact, it is doubtful that such arrangements could be sustained otherwise, given that they largely rely on voluntary commitments.

For instance, while it was certainly advantageous for Brazilian workers in metal and chemical industries to emulate (or to be included in) European-inspired industrial relations practices, and although foreign headquarters and local subsidiaries were generally not amenable to this idea at first, the core member-base of "participating unions" coincided with a fragment of the workforce with which TNCs may accept a dialogue to avoid disrupting production. In the garment industry, the jurisdiction expands dramatically but in this case, a much lighter version of social dialogue prevails, one that is closer to CSR monitoring than to proper industrial relations. Retail networks represent a middle ground, where limited supra-local collective bargaining relieves the pressure of potentially damaging national and international campaigns. In all cases, unions may have taken the initiative, but ultimately companies draw the line that determines where the dialogue ends. Once again, commercial banking offers an illuminating counterpoint to the spectrum of social dialogue-cum-private governance frameworks presented by the other networks. However, this meant that there was much less of a focus on the "recognition" of the network and on the institutionalization of private governance arrangements. Contrary to the conventional wisdom, might it be the case that company-specific strategies based on "social dialogue" practices could reinforce, rather than disturb established divisions?

That does not seem to be the case. First of all, the contested character of the relationship between TUNs and TNCs in Brazil is quite evident. "Social dialogue" is an elastic concept used by unions to describe a variety of demands and, on the whole, they are viewed as part of larger industrial and working-class agendas, and achievements in one company set a higher standard to be pursued in different settings. Unsurprisingly, in all four cases, corporate managers resisted the changes proposed by trade unions, and labor gains were invariably the result of workers' struggles and mobilization. Moreover, union leaders engaged in TUNs in Brazil take advantage of foreign practices and global union initiatives selectively. For instance, even though a global agreement signed between Industriall, IG Metall, and a German metal conglomerate was praised in Germany as a landmark achievement because of its provisions on the creation of a company committee, in the spirit of social partnership, and an online reporting system, in the style of corporate compliance tools, Brazilian union leaders were skeptical about these innovations and when issues arose within the company, they preferred to contact foreign and global unions directly. Even in the garment industry, in which CSR practices have been prevalent, IndustriALL has 
been working to gradually shift the paradigm. While the original GFA signed with Inditex in 2007 leaned heavily on CSR terminology, the notion is absent in the latest version of the agreement, signed in 2019.

\section{Concluding remarks}

The previous section dealt with two main questions. First, in what way and to what extent do TUNs transform existing union boundaries? About this, we have argued that networks incorporate flaws of the existing institutional structures, even as they attempt to overcome some of them. TUNs can therefore be a part of reorganization processes, but they are not likely to break away from established unions completely. Second, are company-targeting approaches that engage social responsibility frameworks trapped by the private authority of TNCs? Here, our conclusion is that TUNS venture into "social dialogue" insofar as it allows them to further union prerogatives and collective bargaining. In a sense, the latter answer depends on the former. Precisely because TUNs are intrinsically connected to an established trade union movement, they are capable of engaging TNCs within the field of corporate governance without succumbing to its limitations, always being pulled back into the realm of industrial relations and collective bargaining.

This leaves out the question of whether trade unions, especially when thought of in terms of institutionalized collective bargaining prerogatives, are the only or the best way of organizing workers in response to TNCs. It is not under dispute that global transformations are changing the nature of work and employment across different settings, and some have noted that established trade unions and collective bargaining frameworks are generally not up to the task (Van der Linden, 2016). The results of our study do not imply that alternatives outside of this scope should be ignored, but they suggest that, in countries such as Brazil, trade unions willing to reach beyond the local to defy powerful TNCs are a viable means of preserving, and under certain conditions expanding, a sphere of social protection and labor rights. Most notably, unlikely other forms of cross-border labor organization, TUNs can scale up the age-old clash between workers and their unions, on one side, and corporations and their managers, on the other. 


\section{References}

Anner, Mark. (2006), "Industrial structure, the state, and ideology: Shaping labor transnationalism in the Brazilian auto industry”. Social Science History, Cambridge, 27 (4): 603-634, janeiro.

AnNer, Mark et al. (2006), "The industrial determinants of transnational solidarity: global interunion politics in three sectors". European Journal of Industrial Relations, [s.l.], 1 (12): 7-27, março.

AntUnes, Ricardo. (2000), "The world of work, the restructuring of production, and challenges to trade unionism and social struggles in Brazil". Latin American Perspectives, Riverside, 6 (27): 9-26, novembro.

Burawoy, Michael. (2010), "From Polanyi to Pollyanna: The false optimism of global labor studies”. Global Labor Journal, New York, 2 (1): 301-313, maio.

Castro, Maria Silvia Portela. (2016), “Ação sindical internacional do setor bancário”. In: Faculdade 28 de Agosto de Ensino e Pesquisa. Cadernos 28 de Agosto. São Paulo, Publisher.

Croucher, Richard \& Cotton, Elizabeth. (2009), Global unions, global business. London, Middlesex Univ. Press.

Cumbers, Andy; Nativel, Corinne \& Routledge, Paul. (2008), "Labor agency and union positionalities in global production networks". Journal of Economic Geography, Oxford, 3 (8): 369-387, fevereiro.

Fairbrother, Peter \& Hammer, Nikolaus. (2005), "Global unions: Past efforts and future prospects”. Relations Industrielles/Industrial Relations, [s.1.], 3 (60): 405-431, verão.

Gallin, Dan. (2008), “International framework agreements: A reassessment”. In: PAPADAKIS, Konstantinos (org.). Cross-border social dialogue and agreements: An emerging global industrial relations framework? Geneva, International Labor Office.

Garver, Paul et al. (2007), "Global labor organizing in theory and practice". Labor Studies Journal, [s.1.], 3 (32): 237-256, setembro.

HADWIGER, Felix. (2018), Contracting international employee participation: Global framework agreements. Hamburg, Springer.

Helfen, Markus \& Fichter, Michael. (2013), “Building transnational union networks across global production networks: Conceptualising a new arena of labor-management relations: building transnational union networks". British Journal of Industrial Relations, Nova Jersey, 3 (51): 553-576, setembro.

InDiTEX. (2020), “Annual reports”. https://www.inditex.com/investors/investor-relations/ annual-reports, consultado em 09/04/2021.

IndustrialL. (2014), Global Worker: The Biannual Magazine of IndustriaLL, 1, May. Available at http://www.industriall-union.org/sites/default/files/uploads/documents/Global-Worker/2014-1/gw_may14_web.pdf. 
Lambert, Rob \& Gillan, Michael. (2009), “'Spaces of hope’? Fatalism, trade unionism, and the uneven geography of capital in white goods manufacturing”. Economic Geography, Oxford, 1 (83): 75-95, fevereiro.

Martin, Scott; Veiga, João Paulo \& Galhera, Katiuscia. (2021), Labor contestation in Walmart Brazil: Limits of global diffusion in Latin America. London, Palgrave.

McCallum, Jamie C. (2013), Global unions, local power. New York, Cornell University Press.

O'Brien, Robert. (2019), Labor internationalism in the global south. Cambridge, Cambridge University Press.

PApAdakis, Konstantinos (ed.). (2011), Shaping global industrial relations. Basingstoke, Palgrave Macmillan.

STEVIS, Dimitris. (2011), “The impacts of international framework agreements: Lessons from the Daimler Case". In: PAPAdakis, Konstantinos; Internationale Arbeitsorganisation (org.). Shaping global industrial relations. Basingstoke, Palgrave Macmillan.

VAN Der Linden, Marcel. (2016), "Global labor: A not-so-grand finale and perhaps a new beginning”. Global Labor Journal, New York, 2 (7): 201-210, maio.

VÉRAs, Roberto. (2006), "Metalworkers, the 'strike festival and the possibilities of a national collective contract". In: SAnTos, Boaventura de Sousa (org.). Another production is possible. London/New York, Verso.

Waterman, Peter \& Wills, Jane (orgs.). (2001), Place, space and new labor internationalisms. Oxford, Blackwell.

Webster, Eddie; Lambert, Rob \& Bezuidenhout, Andries. (2008), Grounding globalization. Oxford, Blackwell.

\section{Abstract}

Cross-border Trade Union Networks in Transnational Corporation: a comparison between sectors This article analyses cross-border trade union networks in Transnational Corporations (TNCs) in the metal and chemical, garment, retail, and commercial banking sectors in Brazil. Conceptualized as global union responses to the growing reach of TNCs, such networks have been established in different settings in the country and have engaged major corporations outside of traditional industrial relations frameworks, venturing into the controversial field of social dialogue, corporate responsibility, and private governance. From different research backgrounds, our findings suggest that union networks in TNCs can be used to rearrange union prerogatives across different levels but remain embedded in previous institutional structures. In this sense, such unions incorporate existing union boundaries, including the exclusion of relevant groups of workers, even as they can scale up the scope of trade union action.

Keywords: Union networks; Transnational corporations; Cross-border organizing. 


\section{Resumo}

Redes sindicais transfronteiriças em corporações transnacionais: uma comparação entre setores Este artigo analisa redes sindicais transfronteiras em Empresas Transnacionais (ETNs) nos setores químico e metalúrgico, confecção do vestuário, comércio e bancário, no Brasil. Conceitualizadas como respostas sindicais globais para a crescente expansão das ETNs, tais redes têm sido estabelecidas em diferentes parâmetros no país, se envolvido com grandes empresas fora das estruturas tradicionais de relações de trabalho e se arriscando no campo controverso do diálogo social, responsabilidade corporativa e governança privada. Partindo de diferentes bagagens metodológicas de pesquisa, nossos resultados sugerem que redes sindicais em ETNs podem ser utilizadas para rearranjar prerrogativas sindicais em diferentes níveis, mas continuam enraizadas em estruturas institucionais prévias. Nesse sentido, tais sindicatos incorporam limites prévios de atuação, como a exclusão de grupos relevantes de trabalhadores(as), mesmo nos casos em que estes(as) podem expandir o campo de ação de sindicatos.

Palavras-chave: Redes sindicais; Corporações transnacionais; Organização transfronteiriça.

Texto recebido em 16/4/2021 e aprovado em 30/4/2021.

DOI: $10.11606 / 0103-2070 . t s .2021 .184497$.

Ricardo Framil Filho is a PhD candidate in sociology at the University of São Paulo. His interests centre on globalization, labour, and social movements, and his doctoral research focuses on struggles within transnational corporations. His latest publications include "From global unions to the shop floor: Trade union networks in transnational corporations in Brazil", Global Labour Journal, 10 (3), 2019, and "Trabalho, sindicatos e proteção social na pandemia de 2020: notas sobre o caso brasileiro”, Ciências Sociais Unisinos, 5 (2), 2020. E-mail: ricardoff@usp.br. Katiuscia Galhera is a professor at the Graduation Program of Sociology at the Federal University of Metropolitan Dourados (UFGD), in Brazil. Her areas of specialization are gender, labor, social movements, transnational corporations, global supply chains and Latin American political economy. She holds a postdoc in Sociology of Work from Londrina State University (Brazil) (2019). Last publication includes the book Labor contestation in Walmart Brazil: Limits of global diffusion in Latin America, London, Palgrave, 2021 (co-authored with Scott Martin e João Paulo Veiga). E-mail: katiuscia.mg1@gmail.com.

Leonardo Mello e Silva teaches sociology at University of São Paulo, Brazil. His researches and areas of interest cover the world of labour in a wide sense: labour process, labour market, unionism, industrial relations, globalization and social movements. He has supervised regularly graduate students interested in those domains. E-mail: leogmsilva@hotmail.com. 